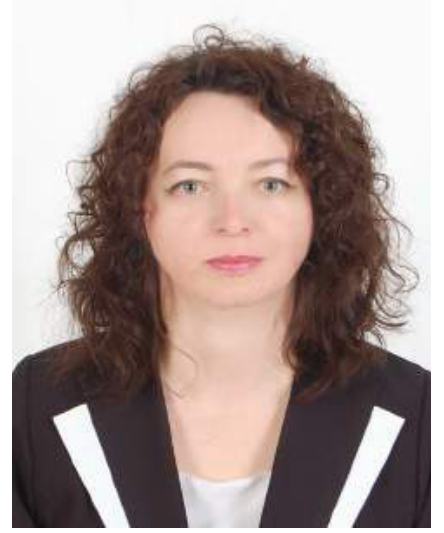

Лариса Наконечна, кандидат філологічних наук, доцент, ДВНЗ «Прикарпатський національний університет імені Василя Стефаника» (м. Івано-Франківськ)

\section{Larysa Nakonechna,}

Candidate of Philology Sciences, Associate Professor, Vasyl Stefanyk Precarpathian National University

(Ivano-Frankivsk)

larysa.nakonechna@pu.if.ua

ID orcid.org/0000-0003-0743-4576

\title{
ПРОБЛЕМА ФОРМУВАННЯ ОРФОГРАФІЧНОЇ ГРАМОТНОСТІ МОЛОДШИХ ШКОЛЯРІВ В УМОВАХ МІСЦЕВОЇ ГОВІРКИ
}

\section{FORMATION ORTHOGRAPHIC COMPETENCE OF ELEMENTARY SCHOOL STUDENTS IN THE CONDITION OF THE REGION DIALECT'S INFLUENCE}

Статтю присвячено проблемі формування орфографічної грамотності учнів початкової школи в умовах говірок південнозахідного наріччя, поширених на території Прикарпаття; описано типові орфографічні помилки, спричинені народним мовленням; проаналізовано вплив говіркової вимови на засвоєння норм орфографії молодшими школярами. Розглянуто погляди на проблему формування орфографічної грамотності в сучасній лінгводидактиці; обгрунтовано практичну цінність орфоепічно правильного мовлення учнів і їхнього оточення для формування орфографічних навичок школярів. Мета статті - розглянути вплив місцевих говірок на засвоєння молодшими школярами орфографічних норм літературної мови, виявити у роботах учнів і описати типові випадки неправильного написання слів, що зумовлені говірками Прикарпаття.

Автор акцентує увагу на тому, що чи не найважливішим чинником ефективного засвоєння молодшими школярами норм орфографії української мови в умовах виразного діалектного середовища, є правильна вимова звуків, звукосполучень і слів.

Методологічними засадами дослідження є науково-концептуальні положення про взаємозв'язок мови, мовлення і мислення, їх визначальне місце і роль у розвитку особистості; концепції побудови освіти на засадах формування національно свідомої мовної особистості. Отже, формуванню орфографічної грамотності молодших школярів належить провідне місце у системі мовної підготовки учнів початкової школи.

Ключові слова: орфографія, орфоепія, літературна норма, діалект, початкова школа.

The article focuses on the formation of orthography competence of elementary school pupils in the condition of the region dialect's influence (subdialects of the southwestern dialect, common in the Precarpathian region). The author describes the typical spelling mistakes, which are caused of the dialect speech, and also analyses dialect influences to formation orthography competence by elementary school pupils. Moreover, the author describes different approaches for the formation of orthography competence in the modern language pedagogy, as well as justifies the practical values correct spelling for the formation oforthography competence. The purpose of the article is considering the influence of region dialects to learning spelling norms of literary language; describing the typical mistakes in writing of words, which are caused by the Precarpathian dialect.

The author pays the considerable attention on that the correct spelling is the most important factor in the effective learning of the norms of the Ukrainian language in conditions of expressive dialectal environment. Methodological basis of analysis is a conceptual provision about the relationship of language, speech and thinking; determining their place and role in the development of an individual; concept of building education on the basis of the formation of the national conscious linguistic personality.

So, the formation of spelling skills belongs to the leading place in the system of language learning of elementary school pupils.

Keywords: orthography, orthoepy, literary language, dialect, elementary school.

Статья посвящена проблеме формирования орфографической грамотности учащихся начальной школы в условиях говоров южно-западного наречия, распространенных на территории Прикарпатья; описано типичные орфографические ошибки, обусловленные народной речью; проанализировано влияние диалектного произношения на изучение норм орфографии младшими школьниками. Рассмотрено взгляды на проблему формирования орфографической грамотности в современной лингводидактике, обосновано практическую ценность орфоэпически правильной речи учащихся и их окружения для формирования орфографических навыков. Цель статьи - рассмотреть влияние местных говоров на усвоение младшими школьниками орфографических норм литературного язика; определить в ученических работах и описать типичные случаи неправильного написания слов, обусловленные говорами Прикарпатья. 
Автор акцентирует внимание на одном из наиболее важных факторов ефективного изучения младшими школьниками норм орфографии украинского языка в условиях выразительной диалектной среды - правильном произношении звуков, звукосочетаний и слов.

Методологическими принципами исследования являются научно-концептуальные положения о взаимосвязи языка, речи и мышления, их определяющее место и роль в развитии личности; концепции развития образования на базисе формирования национально сознательной языковой личности. Итак, формирование орфографической грамотности младших школьников занимает одно из главных мест в системе языковой подготовки учащихся начальной школы.

Ключевые слова: орфография, орфоэпия, литературная норма, диалект, начальная школа.

Постановка проблеми в загальному вигляді та її зв'язок з важливими науковими та практичними завданнями. Орфографічні вміння і навички, тобто ті орфографічні дії, що є основою правильного оформлення думок засобами писемної мови, - беззаперечний показник культури мовлення людини. Досконале володіння правописними нормами свідчить про високий рівень освіченості й грамотності мовця.

Формування орфографічних умінь і навичок учнів початкової школи - процес довготривалий, він потребує немалих зусиль як з боку вчителя, так і учня. Це пов'язано не тільки з особливостями пам'яті дитини, тобто з процесами запам'ятовування і забування, але й із не завжди сприятливим впливом мовного оточення. Саме риси місцевої говірки, носіями якої є учні, часто зумовлюють труднощі в опануванні школярами орфографічних норм літературної мови.

Аналіз останніх досліджень і публікацій, у яких започатковано розв'язання проблеми. Помилки, спричинені діалектним середовищем, давно привертали до себе увагу вчених і вчителів-практиків. На необхідності врахування говіркового фону при вивченні літературної мови і зокрема її правописних норм, неодноразово наголошували у своїх працях О. А. Дорошенко, О. М. Євтушок, Л. М. Симоненкова, І. Хом'як, C. Х. Чавдаров та ін. Однак у методиці викладання української мови це питання залишається актуальним, не вивченим і надзвичайно важливим для процесу вивчення учнями початкової школи норм літературної мови. Адже кожен з місцевих діалектів по-різному співвідноситься з літературною мовою, це зумовлює необхідність встановлення збігів та розбіжностей між нормами певного діалекту й літературної мови, з'ясування типових помилок не тільки в усному, а й писемному мовленні школярів, спричинених саме впливом місцевої говірки, вироблення ефективних прийомів їх подолання.

Формування мети статті. Мета статті - розглянути вплив місцевих говірок на засвоєння молодшими школярами орфографічних норм літературної мови, виявити у роботах учнів і описати типові випадки неправильного написання слів, що зумовлені говірками Прикарпаття.

Виклад основного матеріалу дослідження з повним обґрунтуванням отриманих наукових результатів. В умовах виразного діалектного впливу основними причинами неправильного написання слів $€$ зазвичай говіркові особливості, а саме: фонетичні, орфоепічні, морфологічні, словотвірні відхилення від літературної норми. Лексичні та синтаксичні риси місцевої говірки, як правило, не зумовлюють орфографічних помилок.

Дослідник взаємодії діалектного й літературного мовлення О. В. Текучов окреслив такі групи орфографічних помилок, що спричинені діалектною вимовою:

1) фонетичні - помилки, зумовлені звучанням слова, звукосполучення чи звука;

2) морфологічні - помилки, спричинені особливостями граматичної будови діалекту;

3) фонетико-морфологічні - помилки, викликані як фонетичними, так і морфологічними відмінностями діалектного слова від літературного [за 6, с. 11]. Ця класифікація є прийнятною і зараз.

Чи не найвагомішим чинником порушення орфографічної норми, на чому наголошують науковці та вчителі, $€$ орфоепічні відхилення у мовленні як учнів, так і дорослих з їхнього оточення. Адже звукова система наріч української мови, в тому числі і південно-західного діалекту, вплив якого ми досліджуємо, значно різниться від літературної вимови.

Так, відомий методист XX століття, який з'ясовував вплив фонетичних, морфологічних та лексичних особливостей українських говорів на грамотність учнів, А. О. Загродський наголошував, що саме «недостатня увага до нормативної вимови слова часто буває причиною дуже грубих орфографічних помилок» [за 6, с. 5]. Науковці М. В. Ушаков та М. С. Рождественський, класифікуючи орфограми, беруть до уваги саме зв'язок орфографії з орфоепією і тому розмежовують їх на ті, що зумовлені вимовою, і ті, які вимовою не визначаються [4, с. 111]. І. М. Хомяк, досліджуючи природу орфографічних помилок, зумовлених впливом діалектного оточення, слушно зазначає, що «від уміння школяра вимовляти звуки залежить доцільність методики опрацювання відповідної аналізованому звукові орфограми» [7, с. 27].

3 огляду на це чи не найбільше уваги і дослідники, і вчителі-практики радять приділяти у початковій школі саме навичкам літературної вимови, вмінню відтворити вимовлене слово відповідними буквами, розвиткові «фонетичного слуху, що $є$ основою для формування орфографічної пильності» [3а 4, с. 110]. Адже, як зазначено у пояснювальній записці до програми «Українська мова» для 1-4 класів, основою орфографічної грамотності молодших школярів є вміння зіставляти фонетичний і графічний образи слова, позначати звуки слова відповідними буквами без їх пропусків, замін, вставлянь і переставлянь. Учні початкових класів повинні оволодіти цими уміннями і безпомилково писати слова за фонетичним принципом [5, с. 9]. 
Однак проблема полягає у тому, що учні як носії місцевої говірки нерідко відтворюють саме діалектне звучання слова, а це призводить до порушення його написання. 3 іншого боку, молодші школярі, записуючи промовлене слово, керуються фонетичним принципом орфографії: як чую, так і пишу. Але ж чують зазвичай у повсякденному житті нелітературний варіант, який уважають правильним, оскільки він для них звичний. Так, наприклад, пишуть лисця замість листя, кубіки (=кубики), світит (=світить), палці (=пальці), дожді (=дощі), фустина (=хустина), кісто (=тісто), колюшина (=конюшина). Приклади подаємо з письмових творчих робіт учнів 3-4 класів. Як відомо, фонетичний принцип орфографії української мови є тільки одним із чотирьох, хоча й найбільш поширеним (вважається, що 80 \% написань української мови ґрунтується саме на цьому принципі). Написання слів за іншими принципами (морфологічним, історичним, семантичним) потребує певних міркувань, зусиль думки, пам'яті, тому зазвичай учні і вдаються до фонетичного запису слова.

Проведений низкою дослідників аналіз письмових учнівських робіт засвідчує, що кількість орфографічних помилок, спричинених впливом місцевих говорів, у творчих роботах становить від 27 до $31 \%$, що у 2-3 рази більше, ніж у диктантах (тут їх кількість становить 6-10 \%). Причому помилки в диктантах, як правило, однотипні - переважно пояснюються впливом фонетичних особливостей говірок і повторюються в більшості учнів [6, с. 12].

Ми аналізували вплив говірок південно-західного наріччя, а отже й мовлення молодших школярів як носіїв цих говірок, на орфографічну грамотність учнів. Для цього використали самостійні творчі роботи учнів 3-4 класів шкіл Івано-Франківської області. Саме цей вид робіт як результат невимушеного, некерованого мовлення школярів, $є$ виразним віддзеркаленням впливу діалектного мовного середовища. Брали до уваги орфограми, які учні вже вивчили чи будуть вивчати у початковій школі. Це, вважаємо, дає змогу виявити ті орфограми, вивчення яких дається учням важче за інші, а отже, потребує ретельного закріплення. 3 іншого боку, допоможе передбачити труднощі в опрацюванні нових орфограм і запобігти їм. Так, наприклад, з'ясували низку діалектних варіантів, на які, вважаємо, необхідно буде вчителеві звернути особливу увагу, оскільки зафіксували їх у більшості (майже у 90 \%) робіт. Саме діалектні форми діти вважають правильними. І це не дивно, адже вони їх запам'ятали з повсякденного мовлення. Так, іменники кури, плечі, очі, у формі орудного відмінка учні 3-4 класів подали як курьми, курами, курями (нормативне курми); плечами, плечми, зрідка плечьми (правильно плечима,); очами, очми, (нормативне очима); а іменники ножиці, сорочки, гості в родовому відмінку - як ножиців, ножниців (правильно ножиць), сорочків замість сорочок, гостів замість гостей. Хоча таке написання відмінкових форм іменників не фіксується у початковій школі як помилкове, однак такий аналіз дає змогу з'ясувати звичні для дітей форми і визначити потенційні труднощі в удосконаленні грамотності учнів.

У процесі дослідження зафіксували такі найбільш типові орфографічні помилки, зумовлені діалектним мовним середовищем молодших школярів:

- відсутність ь в особових закінченнях дієслова в результаті ствердіння кінцевого [т]]: лежит, несут, ходит, робит, люблят, кажут,

- відсутність $b$ перед закінченням прикметників з м'якою основою родового, давального, орудного й місцевого відмінків, а також використання літер $a, e, y$, и замість я, $\epsilon$, ю, $i$ у називному відмінку, що зумовлено ствердінням [нґ] у прикметниках: давна, сине, синої (води), ранний, верхний, літною, домашних, домашного.

- ствердіння пом'якшеного [р'] спричинило також використання літер a, у, замість я, ю: гарачка (гарячка), буру (бурю), курам (курям), бурак (буряк);

- виникають орфографічні помилки і при нерозрізненні дзвінких і глухих звуків, при цьому зауважили не тільки оглушення дзвінкого звука в кінці та середині слова, як-от у словах: такош (також), сат (сад), ра들

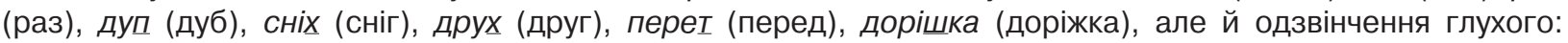
фудбол (футбол), говатися (ховатися), бідіймається (підіймається), годити (ходити), розблачиться (розплачеться), бавивззя (бавився), кородшими (коротшими), найкражчим (найкращим);

- вживання b та I для пом'якшення шиплячих і свистячих приголосних: найкращій (найкращий), очьми, пальчік, їжачьок, свіжя, сонечько, спочьитку, радосьті, щісті (щастя);

- сплутування шиплячих, а також шиплячих і свистячих: черква, чоколадка, душе (дуже), дожді (дощі), нерідко використання [ш] замість [шч] (графічно щ), як правило, з відповідним пом'якшенням шиплячого: найкраший (найкращий), шєстє (щастя), шо, шьо (що), ше, шє (ще), дошь (дощ);

- неправильне вживання ненаголошених [и, е] у словах, де ці голосні перевіряються наголосом: лижит, впиклася, визуть, соничко, висна, весило, систричка, силло, техенько, та у словах, написання яких учні початкової школи повинні запам'ятати: мині, нй (=не), нимма, будимо, пшиниця, ручинята, ножинята, кошинята, бабене літо, ззкочела. Зафіксували навіть підміну цих голосних у наголошеній позиції: цукиркі, налижати.

- вживання [е, и, i] замість [а] після м'яких чи пом'якшених приголосних, хоча спостерігаємо і після твердих приголосних. При цьому зафіксували кілька варіантів відтворення голосного у тій самій позиції в одному і тому ж слові, що свідчить про різні варіанти вимови цих слів, а також про сумніви учнів і їхнє намагання якнайточніше, а отже якнайправильніше, записати слово: занєті, ножинєта, ручинєта, ручиньитами, житє; щастє, щєстє, щьистьи, щисти, щисті; пальцєма, пальцьима, пальціма, пальцьома. 
- закінчення -ов, -ев замість нормативного -ою, -ею в іменниках I відміни, прикметниках, займенниках та числівниках в орудному відмінку однини: за мамов, курков, руков, бурьов, веснов, за границьов, синьов, зеленов, пшеничнов муков, зо мнов, другов;

- написання закінчення -і замість -ій у прикметниках давального та місцевого відмінків однини жіночого роду: у нові школі, малі дитині, на високі сосні;

- використання закінчення -і замість -и як результат впливу пом'якшення кінцевого приголосного іменників II відміни множини на -к-: цукеркі, батончикі, подарункі;

- усічення особового закінчення дієслів 1-ї особи множини теперішнього часу: робим (робимо), ходим, носим, любим, ліпим;

- написання особового закінченнях дієслів 3-ї особи однини і множини теперішнього і майбутнього часу на -ться фонетичним варіантом -ця, -ся (-си) нерідко з підміною є та ї: граїси, граїся (грається), смієця, смієся (сміється) боєси (боїться), підіймаєця, підоймаєся (підіймається), подобаєси (подобається), розплачеся (розплачеться). Навіть при використанні дієслівної кінцівки -ться часто опускається м'який знак: дивитси, підоймаєтся, розплачится.

Безперечно, кількість помилок, що виникають під впливом місцевих говорів, зменшується із класу в клас, проте зменшується повільно, оскільки вони є досить стійкими, характерними здебільшого для всіх мовців 3 оточення школяра і сприймаються ними як нормативні в усіх мовленнєвих ситуаціях. Тому роботу над засвоєнням літературної правописної норми у початковій школі необхідно проводити постійно, не тільки на уроках читання і письма. Адже саме в цей шкільний період закладається основа для наступного, більш свідомого оволодіння літературною нормою Важливо, щоб учні завжди чули нормативне мовлення вчителя, привчалися сприймати на слух нетрадиційні для них словоформи і фонетичне оформлення відомих їм слів.

Висновки і перспективи подальших досліджень. Отож орфографічні недоліки у письмових роботах учнів молодших класів значною мірою спричинені впливом діалектного середовища, а саме усного народного мовлення. Цілком погоджуємося з думкою О. А. Дорошенка про те, що "врахування особливостей місцевого говору при викладанні української мови в школі - необхідна умова успішної роботи вчителя над піднесенням культури усної і писемної мови учнів" [2, с. 5].

Подальший пошук ефективних шляхів формування мовної особистості молодшого школяра на фоні виразного діалектного мовлення вбачаємо у всебічному аналізі впливів лінгвальних і ексталінгвальних чинників на процес навчання української літературної мови у початковій школі.

1. Бевзенко С. П. Українська діалектологія / С. П. Бевзенко - К.: Вища школа, 1980. - 246 с.

2. Дорошенко О. А. Робота вчителя-словесника в умовах місцевої говірки / О. А. Дорошенко // Українська мова і література в школі. - 1991. - № 12. - С.18 - 22.

3. Євтушок О. М. Про стан і деякі аспекти вивчення діалектної лексики / О. М. Євтушок // Українська мова і література в школі. - 1992. - № 2. - С. 3-5.

4. Коваль Н. С. Методика викладання української мови / Н. С. Коваль, Н. І. Деркач, М. М. Наумчук. - Тернопіль, 2008. - 287 c.

5. Навчальна програма для загальноосвітніх навчальних закладів 1 - 4 класи. Українська мова. - [Електронний ресурс]. Ресурс доступу: http://mon.gov.ua/activity/education/zagalna-serednya/pochatkova-shkola.html

6. Симоненкова Л. М. Вивчення фонетики і морфології в умовах місцевих говорів / Л. М. Симоненкова. - К., $1981 .-134$ с.

7. Хом'як І. М. Характер орфографічних утруднень, викликаних мовленнєвим середовищем / І. М. Хом'як // Наукові записки Національного університету «Острозька академія». Серія «Психологія і педагогіка». 2014. - Випуск 29 - С. $26-29$.

\section{Reference}

1. Bevzenko S. P. Ukrainska dialektolohiia/ S. P. Bevzenko. - K.: Vyshcha shkola, 1980. - $246 \mathrm{s.}$

2. Doroshenko O. A. Robota vchytelia-slovesnyka v umovakh mistsevoi hovirky / O. A. Doroshenko // Ukrainska mova i literatura v shkoli. - 1991. - № 12. - S.18 - 22.

3. levtushok O. M. Pro stan i deiaki aspekty vyvchennia dialektnoi leksyky / O. M. levtushok // Ukrainska mova i literatura v shkoli. 1992. - № 2. - S. 3-5.

4. Koval N. S. Metodyka vykladannia ukrainskoi movy / N. S. Koval, N. I. Derkach, M. M. Naumchuk. - Ternopil, $2008 .-287$ s.

5. Navchalna prohrama dlia zahalnoosvitnikh navchalnykh zakladiv 1 - 4 klasy. Ukrainska mova. - [Elektronnyi resurs]. - Resurs dostupu: http://mon.gov.ua/activity/education/zagalna-serednya/pochatkova-shkola.html

6. Symonenkova L. M. Vyvchennia fonetyky i morfolohii v umovakh mistsevykh hovoriv / L. M. Symonenkova. - K., 1981. - $134 \mathrm{~s}$.

7. Khomiak I. M. Kharakter orfohrafichnykh utrudnen, vyklykanykh movlennievym seredovyshchem / I. M. Khomiak // Naukovi zapysky Natsionalnoho universytetu «Ostrozka akademiia». Seriia «Psykholohiia i pedahohika». 2014. - Vypusk 29 - S. 26-29. 